AdAm NieWIADOMSKI ${ }^{1}$

\title{
Problematyka prawna rekompensat za ustanowienie formy ochrony przyrody - obszarów Natura 2000 na obszarach wiejskich
}

Regulacje dotyczące obszarów Natura 2000 w polskim systemie prawnym mają już ponad dziesięcioletnią tradycję. Wprowadzone w wyniku realizacji postanowień dyrektyw europejskich, jako jedna $\mathrm{z}$ form ochrony przyrody w ustawie $\mathrm{z}$ dnia 16 kwietnia 2004 r. o ochronie przyrody ${ }^{2}$ stanowią ważne dla funkcjonowania polskiego rolnictwa obszary o szczególnym znaczeniu przyrodniczym. ${ }^{3}$ Wspomnieć tylko należy, że obecnie obszary Natura 2000 zajmują około 20\% powierzchni lądowej Polski. Ze względu na status prawny jest to 849 obszarów siedliskowych i 145 obszarów ptasich. ${ }^{4}$

Na każdym z tych obszarów obowiązują odrębne przepisy prawne określające ich funkcjonowanie. Daje to w sumie prawie tysiąc aktów prawa powszechnie obowiązującego, które powinny realizować nie tylko postanowienia regulacji europejskich, ustawowych, ale przede wszystkim odpowiadać lokalnym potrzebom środowiskowym. Akty te ingerują także w sferę prawa cywilnego określając sposób wykonywania prawa własności. Z uwagi, że większość obszarów Natura 2000 znajduje się na obszarach o charakterze rolniczym, określone w planach ochrony dla obszarów Natura 2000 oraz w planach zadań ochronnych obowiązki właścicieli nieruchomości dotyczą rolników. Gospodarowanie przez nich na obszarach Natura 2000, czyli terenach o szczególnym znaczeniu przyrodniczym, nakłada na nich szczególny rodzaj zobowiązań wynikających z regulacji ochrony przyrody. Zobowiązania te powstające w wyniku aktu prawa publicznego stoją niejednokrotnie w konflikcie z prawami właściciela wynikającymi z regulacji cywilnoprawnych. Znalezienie właściwego sposobu funkcjonowania rolników na tych obszarach, bez większego

\footnotetext{
Badania zostały sfinansowane ze środków Narodowego Centrum Nauki przyznanych w ramach finansowania stażu po uzyskaniu stopnia naukowego doktora na podstawie decyzji numer DEC-2012/04/S/HS5/00338.

Uniwersytet w Białymstoku, Uniwersytet Warszawski.

Tekst jednolity Dz.U. z 2013 r. poz. 627 z późn. zm.

A. Bołtromiuk (red.), Europejska Sieć Ekologiczna Natura 2000 jako nowy element otoczenia polskiej wsi i rolnictwa, Warszawa 2010.

4 Strona internetowa Generalnej Dyrekcji Ochrony Środowiska - dostęp dnia 30.12.2014 r.
} 
uszczerbku dla ich sytuacji ekonomicznej, stanowi ważne wyzwanie dla pomocowych regulacji europejskich, jak także prawa krajowego. ${ }^{5}$

Poza systemem pomocowym wynikającym z Programów Rozwojów Obszarów Wiejskich ${ }^{6}$ oraz odpowiednich postanowień planów ochrony dla obszarów Natura 2000 oraz planów zadań ochronnych obszary Natura 2000 nabierają szczególnego znaczenia dla rolników po 2014 r., kiedy stały się od 1 stycznia 2015 r. na mocy rozporządzenia Parlamentu Europejskiego i Rady (UE) nr 1307/2013 z dnia 17 grudnia 2013 r. ustanawiające przepisy dotyczące płatności bezpośrednich dla rolników na podstawie systemów wsparcia w ramach wspólnej polityki rolnej oraz uchylające rozporządzenie Rady (WE) nr 637/2008 i rozporządzenie Rady (WE) nr 73/20097 elementem nowej ,zielonej” Wspólnej Polityki Rolnej. Obszary Natura 2000 zyskały kolejne podstawy prawne do wzmocnionej ochrony przyrody na tych terenach. ${ }^{8}$ Ta dwoistość regulacji budzi zresztą poważne problemy prawne, prowadzące niejednokrotnie do konfliktu. ${ }^{9}$

Wprowadzenie tych nowych regulacji aktem prawnym bezpośrednio stosowalnym ${ }^{10} \mathrm{w}$ państwie członkowskim nakłada na wszystkich rolników, a na rolników gospodarujących na obszarach Natura 2000 w szczególności, nowe obowiązki związane z dostępem do systemu płatności obszarowych. Wypełnienie nowych zobowiązań może okazać się sprzeczne z obowiązującymi postanowieniami nie tylko prawa publicznego (jak wspomniane plany dotyczące obszarów Natura $2000^{11}$ ), ale także umownych (prywatnoprawnych) zobowiązań rolno-środowiskowych, a od 2015 r. rolno-środowiskowo-klimatycznych.

Obowiązująca polska ustawa oraz dwie dyrektywy europejskie: dyrektywa Parlamentu Europejskiego i Rady 2009/147/WE z dnia 30 listopada 2009 r. w sprawie ochrony dzikiego ptactwa ${ }^{12}$ oraz dyrektywa Rady 94/43/EWG z dnia 21 maja

P. Czechowski, A. Niewiadomski, Tendencje rozwoju polskiego prawa rolnego w związku z nabyciem członkostwa Polski w Unii Europejskiej, „Studia luridica Agraria” 2009, t. VII, s. 30-45.

6 A. Jurcewicz (red.), Prawo i polityka rolna Unii Europejskiej, Warszawa 2010; A. Jurcewicz, Wspólna polityka rolna Unii Europejskiej, [w:] A. Stelmachowski (red.), Prawo rolne, Warszawa 2009, s. 85-94.

Dz.Urz. UE L 347 z 20.12.2013 r., s. 608 z późn. zm.

P. Czechowski, A. Niewiadomski, Tendencje rozwoju polskiego prawa rolnego..., op. cit., s. 30-45.

A. Niewiadomski, European Ecological Network Natura 2000 - Opportunities and Threats, "International Journal of Environmental Science and Engineering" 2013, Vol. 7, No 9, s. 9-16; M. Deutsch, P. Coleman, Rozwiązywanie konfliktów: teoria i praktyka, Kraków 2005; M. Dutkowski, Konflikty w gospodarowaniu dobrami środowiskowymi, Gdańsk 1995.

10 A. Stelmachowski, Problemy harmonizacji prawa w związku z integracją polskiego rolnictwa z Unią Europejską (koreferat), [w:] Prawo rolne u progu Unii Europejskiej, S. Prutis (red.), Białystok 1998; A. Jurcewicz, Traktatowe podstawy unijnego prawa rolnego w świetle orzecznictwa. Zagadnienia wybrane, Warszawa 2012.

A. Lipiński, Planowanie ochrony obszarów Natura 2000, [w:] Problemy wdrażania systemu Natura 2000 w Polsce, A. Kaźmierska-Patrzyczna, M.A. Król (red.), Szczecin-Lódź-Poznań 2013, s. 341-357; E. Zębek, Plany zadań ochronnych jako prawny instrument ochrony obszarów Natura 2000 w województwie warmińsko-mazurskim, [w:] Problemy wdrażania systemu Natura 2000 w Polsce, A. Kaźmierska-Patrzyczna, M.A. Król (red.), Szczecin-Łódź-Poznań 2013, s. 359-374.

Dz.Urz. UE L 20 z 26.01.2010 r., s. 7 z późn. zm. - wcześniej była to dyrektywa Rady 79/409/EWG z dnia 2 kwietnia 1979 r. w sprawie ochrony dzikich ptaków - Dz.Urz. WE L 103 z 25.07.1979 r., s. 1 z późn. zm. - zwaną „dyrektywą ptasią", nazwa ta przyjęła się również do obecnej regulacji. 
1992 r. w sprawie ochrony siedlisk przyrodniczych oraz dzikiej fauny i flory ${ }^{13}$ chroniąc cenne obszary w istotny sposób uniemożliwiają korzystanie rolnikom z ich nieruchomości, które znajdują się na obszarach Natura 2000. Uniemożliwiają przede wszystkim rozwój rolnictwa ekstensywnego. ${ }^{14}$

Z naukowej rzetelności należy zaznaczyć, że i w Programie Rozwoju Obszarów wiejskich na lata 2007-2013 i tym na lata 2014-2020 ${ }^{15}$ przewidziano odpowiednie środki finansowe dla rolników prowadzących działalność rolniczą na obszarach Natura 2000. ${ }^{16}$ Większego znaczenia nabiera także finansowanie rolnictwa ekologicznego, które przeżywa rozwój na tych terenach.

Głównym problemem dla rolników jest jednak sytuacja istotnego ograniczenia wykonywania ich prawa własności nieruchomości ${ }^{17}$ na obszarach Natura 2000. Ograniczenia te wynikają nie tylko z ustawy i wspomnianych dyrektyw, ale przede wszystkim z aktów prawa miejscowego, jakimi są plany zadań ochronnych, które w sposób szczegółowy określają możliwości prowadzenia działalności rolniczej na danym terenie objętym regulacjami obszarów Natura 2000. Regulacje te mogą istotnie ograniczyć lub nawet zakazać prowadzenia działalności rolniczej. ${ }^{18}$ Powstaje wtedy problem, czy rolnikowi, poza środkami europejskimi, pozostaje jakaś prawna możliwość obrony swojego warsztatu pracy. ${ }^{19}$

Dz.Urz. WE L 206 z 22.07.1992 r., s. 7 z późn. zm. - zwaną „dyrektywą siedliskową”.

14 P. Czechowski, A. Niewiadomski, Wpływ funduszy strukturalnych na wzrost konkurencyjności polskiego rolnictwa - aspekty prawne, „Studia luridica Agraria” 2012, t. X, s. 326-334; A.Z. Nowak, A. Niewiadomska, Wpływ funduszy strukturalnych na wzrost konkurencyjności polskiego rolnictwa - wybrane aspekty ekonomiczne, „Studia luridica Agraria" 2012, t. X, s. 307-325; P. Czechowski, A. Niewiadomska, A. Niewiadomski, A.Z. Nowak, Wpływ funduszy strukturalnych na wzrost konkurencyjności polskiego rolnictwa, Warszawa 2013.

15 E. Tomkiewicz, M. Bocheński, Polityka rozwoju obszarów wiejskich w perspektywie lat 2014-2020 w kontekście nowych wyzwań, „Studia luridica Agraria” 2012, t. X, s. 239-250.

16 M.A. Król, Obszary o wysokich wartościach przyrodniczych i ich znaczenie w ochronie różnorodności biologicznej na obszarach wiejskich, [w:] Administracja publiczna a ochrona przyrody. Zagadnienia ekonomiczne, społeczne oraz prawne, M. Górski, D. Niedziółka, R. Stec, D. Strus (red.), Warszawa 2012, s. 47-66.

17 W. Pańko, O prawie własności i jego współczesnych funkcjach, Katowice 1984.

18 Zgodnie z art. 28 ust. 10 ustawy o ochronie przyrody plan zadań ochronnych zawiera: „opis granic obszaru i mapę obszaru Natura 2000; identyfikację istniejących i potencjalnych zagrożeń dla zachowania właściwego stanu ochrony siedlisk przyrodniczych oraz gatunków roślin i zwierząt i ich siedlisk będących przedmiotami ochrony; cele działań ochronnych; określenie działań ochronnych ze wskazaniem podmiotów odpowiedzialnych za ich wykonanie i obszarów ich wdrażania, w tym w szczególności działań dotyczących: ochrony czynnej siedlisk przyrodniczych, gatunków roślin i zwierząt oraz ich siedlisk, monitoringu stanu przedmiotów ochrony oraz monitoringu realizacji celów, o których mowa w pkt 3, uzupełnienia stanu wiedzy o przedmiotach ochrony i uwarunkowaniach ich ochrony; wskazania do zmian w istniejących studiach uwarunkowań i kierunków zagospodarowania przestrzennego gmin, miejscowych planach zagospodarowania przestrzennego, planach zagospodarowania przestrzennego województw oraz planach zagospodarowania przestrzennego morskich wód wewnętrznych, morza terytorialnego i wyłącznej strefy ekonomicznej dotyczące eliminacji lub ograniczenia zagrożeń wewnętrznych lub zewnętrznych, jeżeli są niezbędne dla utrzymania lub odtworzenia właściwego stanu ochrony siedlisk przyrodniczych oraz gatunków roślin i zwierząt, dla których ochrony wyznaczono obszar Natura 2000; wskazanie terminu sporządzenia, w razie potrzeby, planu ochrony dla części lub całości obszaru."

19 W. Radecki, Ograniczenie własności ze względu na potrzeby szczególnej ochrony przyrody, [w:] Ochrona środowiska a prawo własności, J. Sommer (red.), Wrocław 2000, s. 29 i n.; R. Budzinowski, Problemy ogólne prawa rolnego, Poznań 2008; D. Łobos, Model gospodarstwa rodzinnego w ustawodawstwie Wspólnot Europejskich oraz w ustawodawstwach narodowych państw członkowskich Wspólnot Europejskich, [w:] Prawo rolne u progu Unii Europejskiej, S. Prutis (red.), Białystok 1998; A. Lichorowicz, Status prawny gospodarstw rodzinnych w ustawodawstwie krajów Europy Zachodniej, Białystok 2000; T. Kurowska, Gospodarstwo rodzinne czy gospodarstwo rozwojowe. Dylematy wyboru, [w:] Prawo rolne u progu Unii Europejskiej, S. Prutis (red.), Białystok 1998; B. Je- 
Polski system prawny przewiduje w tym zakresie jedynie ochronę obejmującą system odszkodowawczy, który aktywizuje się w przypadku ustanowienia na danym terenie obszaru Natura 2000. Zgodnie z prawem objęcie danego terenu obszarem Natura 2000 nie powoduje ograniczenia działalności gospodarczej, leśnej, łowieckiej i rybackiej, jeżeli taka działalność nie oddziałuje znacząco negatywnie na cele ochrony obszaru Natura 2000. Procedura wydawania planów zadań ochronnych przewiduje nawet, że w przypadkach szczególnie uzasadnionych można zezwolić na prowadzenie działalności znacząco negatywnie oddziałującej na cele ochrony obszaru Natura 2000, zapewniając jednocześnie odpowiedni system kompensacji przyrodniczej. Tego typu wyłom w systemie bezwzględnej ochrony przyrody kłóci się jednak z polityką greeningu, która nie przewiduje takich szczególnych przypadków. Jak zostanie rozwiązany ten konflikt pomiędzy obowiązującym prawem krajowym a nowym rozporządzeniem europejskim, czas pokaże. Można jedynie prognozować, iż przeważą w podejmowaniu decyzji przez poszczególnych rolników względy ekonomiczne i ich ocena, podporządkowanie którym regulacjom im się bardzie opłaca. $\mathrm{Z}$ punktu widzenia prawnego takie stosowanie prawa poprzez pryzmat wartości ekonomicznej należy ocenić jako zjawisko niebezpieczne, gdyż może to nie tylko zahamować ochronę przyrody, ale spowodować poważny uszczerbek w zasadzie zaufania obywateli do państwa prawa.

Ustanowienie na danym terenie obszaru Natura 2000 może wiązać się nie tylko z nowymi obowiązkami i prawami, ale także ze zmniejszeniem wartości nieruchomości objętych obszarem lub zmniejszeniem dochodowości prowadzonej działalności na danym obszarze. Rolnik, który przed ustanowieniem takiego obszaru właściwie w sposób nieograniczony korzystał ze swojej nieruchomości, musi się poddać nowemu reżimowi prawnemu, który w istotny sposób ingeruje w przysługujące mu prawo własności. Regulacje te za przedmiot stawiają sobie podstawowy warsztat pracy każdego rolnika, jakim są grunty rolne. Ograniczenie prawa własności nie jest jednakże jedynym problemem w sytuacji ustanowienia obszarów Natura 2000. Nowy system gospodarowania na tych obszarach może spowodować istotny spadek dochodów rolniczych, poprzez wprowadzenie zakazów dotyczących tradycyjnego rolnictwa.

Ustawodawca polski przewidział w zakresie tzw. rekompensat dwie możliwe sytuacje. ${ }^{20}$

Ogólna podstawa roszczeń związanych z wszelkimi naruszeniami związanymi z ograniczeniem sposobu korzystania z nieruchomości w związku z ochroną środo-

żyńska, Wspólnotowa typologia gospodarstw rolnych. Zagadnienia wybrane, „Studia luridica Agraria” 2009, t. VII, s. $129-141$. 
wiska zawarta jest w Prawie ochrony środowiska. ${ }^{21}$ Regulacja ta obejmuje swym zakresem zarówno roszczenia powstałe w wyniku ustanowienia sieci obszarów Natura 2000, jak też parków narodowych, ${ }^{22}$ czy jakiejkolwiek innej formy ochrony przyrody. Zgodnie z wyrokiem Sądu Apelacyjnego w Warszawie z dnia 8 lipca 2011 r. (VI ACa 140/11): „w świetle art. 129 ust. 1 i 2 [...] p.o.ś. podstawą do zgłaszania roszczeń odszkodowawczych jest ograniczenie sposobu korzystania z nieruchomości przez stworzenie obszaru ograniczonego użytkowania”. Za taki obszar ograniczonego użytkowania z całą pewnością należy uznać ustanowienie na danym terytorium obszarów Natura 2000, które w istotny sposób ograniczają dotychczasowe rolnicze gospodarowanie tymi nieruchomościami.

Rolnikowi przysługuje roszczenie żądania wykupienia nieruchomości lub jej części przewidziane w art. 129 ust. 1 ustawy z dnia 27 kwietnia 2001 r. - Prawo ochrony środowiska, ${ }^{23}$ jeżeli w związku z ograniczeniem sposobu korzystania z nieruchomości lub z jej części korzystanie w dotychczasowy sposób lub zgodny z dotychczasowym przeznaczeniem stało się niemożliwe. ${ }^{24}$ Możliwość wystapienia z takim roszczeniem przysługuje właścicielowi nieruchomości oraz użytkownikowi wieczystemu. To pierwsze roszczenie wydaje się najpełniejszym spełnieniem oczekiwań rolnika, który wskutek ustanowienia obszarów Natura 2000 doznał szkody. Problemem jak zawsze w tego typu roszczeniach jest kwestia rzetelnej wyceny nieruchomości, która odpowiadałaby nie tylko wartości nieruchomości, ale również utraconej możliwości pobierania z niej korzyści, w tym pożytków.

Zgodnie z art. 129 ust. 2 Prawa ochrony środowiska właściciel nieruchomości, użytkownik wieczysty oraz osoba, której przysługuje prawo rzeczowe do nierucho-

A. Kozińska, Administracyjna odpowiedzialność za działania, mogące znacząco negatywnie oddziaływać na cele ochrony obszaru Natura 2000, spełniające kryteria szkody w środowisku - stan obecny oraz propozycje nowych rozwiązań prawnych, [w:] Administracja publiczna a ochrona przyrody. Zagadnienia ekonomiczne, społeczne oraz prawne, M. Górski, D. Niedziółka, R. Stec, D. Strus (red.), Warszawa 2012, s. 321-330.

J. Ciechanowicz McLean, Parki Narodowe w prawnym systemie ochrony przyrody, [w:] Administracja publiczna a ochrona przyrody. Zagadnienia ekonomiczne, społeczne oraz prawne, M. Górski, D. Niedziółka, R. Stec, D. Strus (red.), Warszawa 2012, s. 117-124.

23 Tekst jedn. Dz.U. z 2013 r. poz. 1232 z późn. zm.

24 Por. wyrok Sądu Najwyższego z dnia 27 czerwca 2012 r., sygn. IV CSK 28/12: „Odpowiedzialność odszkodowawczą, o której mowa w art. 129 p.o.ś., przewidziano nie za samo ograniczenie i nie za każde ograniczenie sposobu korzystania z nieruchomości. Odszkodowanie nie rekompensuje zmiany dotychczasowej sytuacji właściciela nieruchomości, a tym bardziej utrzymywania już istniejących ograniczeń w przypadku zmiany aktu prawnego. Odszkodowanie służy bowiem za konkretną szkodę, która powstała w związku z ograniczeniem sposobu korzystania z nieruchomości, a nie za samo ograniczenie sposobu korzystania z nieruchomości. Konieczną przesłanką odpowiedzialności odszkodowawczej jest więc szkoda, której źródłem jest rozporządzenie lub akt prawa miejscowego powodujący ograniczenie sposobu korzystania z nieruchomości. Szkoda ma być normalnym następstwem wejścia w życie rozporządzenia lub aktu prawa miejscowego wprowadzającego ograniczenia w sposobie korzystania z nieruchomości. Szkoda taka może powstać, gdy akt prawa miejscowego wprowadza nowe lub zwiększa dotychczasowe ograniczenia co do sposobu korzystania z nieruchomości lub też przedłuża na kolejny okres ograniczenia, które zostały wprowadzone na określony czas. Szkoda nie powstaje, gdy kolejny akt prawny utrzymuje zakres ograniczeń na dotychczasowym poziomie (jak poprzednio obowiązujący)". P. Czechowski, A. Niewiadomski, Europejskie regulacje prawne w zakresie odpowiedzialności za szkodę w środowisku w związku z działalnością rolniczą i produkcją żywności, [w:] Odpowiedzialność za szkodę w środowisku, B. Rakoczy (red.), Toruń 2010, s. 47-62. 
mości (w doktrynie przyjęto, że są to także użytkownicy nieruchomości oraz osoby posiadające prawo dożywocia, zgodnie z art. $910 \mathrm{kc} .^{25}$ ) mogą żądać odszkodowania za poniesioną szkodę, w tym za zmniejszenie wartości nieruchomości. Odszkodowanie to nie jest ograniczone do rzeczywistej straty, obowiązuje bowiem zasada pełnej odpowiedzialności odszkodowawczej za wprowadzenie ograniczeń w korzystaniu z nieruchomości, opartej także na zasadach prawa cywilnego przewidzianych w art. $361 \S 2$ Kodeksu cywilnego. ${ }^{26}$ Zgodnie z art. 129 ust. 4 Prawa ochrony środowiska możliwość wystąpienia z oboma żądaniami jest ograniczona do 2 lat od dnia wejścia w życie rozporządzenia lub aktu prawa miejscowego powodującego ograniczenie sposobu korzystania z nieruchomości. ${ }^{27}$ Powstanie szkody należy jednak ocenić w momencie opublikowania aktu lub w krótkim okresie jego obowiązywania. ${ }^{28}$ Zgodnie z cytowanym orzeczeniem ,nie wyłącza jednak prawa dochodzenia roszczeń powstałych w następstwie wprowadzonych ograniczeń, które nastąpią bez związku z treścią tych ograniczeń, ale z działalnością podmiotu, na którego rzecz ograniczenie nastąpiło, na co wskazuje odesłanie do przepisów Kodeksu cywilnego w art. 322 p.o.ś.” Zgodnie z najnowszym orzecznictwem sądowym „wprowadzenie zmian struktury i ograniczeń obszaru ograniczonego użytkowania otwiera przewidziany w art. 129 ust. 4 p.o.ś. termin zawity jedynie dla roszczeń odszkodowawczych przewidzianych w art. 129 ust. 1-3 tej ustawy, pozostających w związku przyczynowym z dokonanymi zmianami." 29

E. Janeczko, Niektóre cywilnoprawne problemy ochrony środowiska, „Rejent” 2002, nr 11, s. 61 i n. Wyrok SN z dnia 25 lutego 2009 r., sygn. III CSK 546/08.

Zgodnie z wyrokiem Sądu Najwyższego z dnia 4 grudnia 2013 r., sygn. II CSK 161/13: „Jeśli art. 129 ust. 4 p.o.ś. ustanawia dwuletni termin do wystąpienia z roszczeniem, rozumianym jako zgłoszenie roszczenia zobowiązanemu, to jego znaczenie wyczerpuje się z chwilą dokonania takiego zgłoszenia. O przerwie biegu terminu można mówić wówczas, kiedy czynność ograniczona tym terminem nie została wykonana, lecz przed upływem terminu strony podjęły inne działania wskazujące na wolę dobrowolnego zrealizowania obowiązku, dla którego istotne znaczenie miała terminowa czynność. Jeżeli jednak w terminie wykonano czynność docelową, to czynność ta osiąga skutek, kończąc bieg terminu. [...] Roszczenie przewidziane w art. 129 ust. 2 p.o.ś. przedawnia się w terminie ogólnym z art. 118 k.c. Termin ten biegnie od chwili powstania roszczenia - to znaczy od dnia wprowadzenia ograniczeń korzystania z nieruchomości w drodze ustanowienia obszaru ograniczonego użytkowania, od tego momentu bowiem roszczenie jest wymagalne i może być dochodzone od zobowiązanego".

28 Wyrok SN z 25 lutego 2009 r., sygn. III CSK 565/08.

29 Wyrok Sądu Apelacyjnego w Poznaniu z dnia 26 czerwca 2014 r., sygn. I ACa 389/14; podobnie wskazano w wyroku Sądu Apelacyjnego w Warszawie z dnia 21 listopada 2013 r., sygn. VI ACa 682/13: „Odpowiedzialność odszkodowawczą, o której mowa w art. 129 p.o.ś., przewidziano nie za samo ograniczenie i nie za każde ograniczenie sposobu korzystania z nieruchomości. Odszkodowanie nie rekompensuje zmiany dotychczasowej sytuacji właściciela nieruchomości, a tym bardziej utrzymywania już istniejących ograniczeń w przypadku zmiany aktu prawnego. Odszkodowanie służy bowiem za konkretną szkodę, która powstała w związku z ograniczeniem sposobu korzystania z nieruchomości, a nie za samo ograniczenie sposobu korzystania z nieruchomości. Konieczną przesłanką odpowiedzialności odszkodowawczej jest więc szkoda, której źródłem jest rozporządzenie lub akt prawa miejscowego powodujący ograniczenie sposobu korzystania z nieruchomości. Szkoda ma być normalnym następstwem wejścia w życie rozporządzenia lub aktu prawa miejscowego wprowadzającego ograniczenia w sposobie korzystania z nieruchomości. Szkoda taka może powstać, gdy akt prawa miejscowego wprowadza nowe lub zwiększa dotychczasowe ograniczenia co do sposobu korzystania z nieruchomości lub też przedłuża na kolejny okres ograniczenia, które zostały wprowadzone na określony czas. Szkoda nie powstaje, gdy kolejny akt prawny utrzymuje zakres ograniczeń na dotychczasowym poziomie (jak poprzednio obowiązujący)". E. Czech, Szkoda w obszarze środowiska i wina jako determinanty odpowiedzialności administracyjnej za szkodę, Białystok 2008. 
Roszczenia przewidziane w art. 129 Prawa ochrony środowiska podlegają dochodzeniu na drodze cywilnoprawnej zgodnie z procedurą cywilną. Przesądza o tym art. 136 ust. 1 Prawa ochrony środowiska, który wskazuje, że „w razie ograniczenia sposobu korzystania ze środowiska w wyniku ustanowienia obszaru ograniczonego użytkowania właściwymi w sprawach spornych dotyczących wysokości odszkodowania lub wykupu nieruchomości są sądy powszechne. Rodzi to uzasadnione obawy, czy niezamożni rolnicy będą mieli wystarczające środki finansowe, aby chronić swoje prawo własności na drodze cywilnoprawnego powództwa sądowego. Zgodnie z postanowieniem Sądu Najwyższego z dnia 9 kwietnia 2010 r. (III CZP 17/10) „przepisy art. 435 k.c. w związku z art. 322 p.o.ś. i art. 129 p.o.ś. przewidują rozłączne reżimy odpowiedzialności. Za taką interpretacją przemawia również dążenie do kompleksowego uregulowania skutków ustanowienia obszaru ograniczonego użytkowania w zakresie szkody polegającej na obniżeniu wartości nieruchomości. Rozszczepienie tych skutków na szkody wynikające z ograniczeń przewidzianych wprost w rozporządzeniu o ustanowieniu obszaru ograniczonego użytkowania oraz szkody wynikające w emisji hałasu byłoby zresztą sztuczne".

Podmiotem zobowiązanym, zgodnie $\mathrm{z}$ art. 136 ust. 2 Prawa ochrony środowiska, do wypłaty odszkodowania lub wykupu nieruchomości jest ten, którego działalność spowodowała wprowadzenie ograniczeń w związku z ustanowieniem obszaru ograniczonego użytkowania. W przypadku obszarów Natura 2000 podmiotem tym de facto będzie Skarb Państwa. ${ }^{30}$

W przypadku wyboru przez rolnika dochodzenia roszczeń wskazanych w art. 129 Prawa ochrony środowiska, zgodnie z ust. 5 tego artykułu nie stosuje się przepisów ustawy o planowaniu i zagospodarowaniu przestrzennym, dotyczących roszczeń z tytułu ograniczenia sposobu korzystania z nieruchomości. Dotyczy to roszczeń przewidzianych w art. 36 ust. 1 ustawy z dnia 27 marca 2003 r. o planowaniu i zagospodarowaniu przestrzennym. ${ }^{31}$ Regulacja ta dopuszcza „w związku z uchwaleniem planu miejscowego albo jego zmianą, korzystanie z nieruchomości lub jej części w dotychczasowy sposób lub zgodny z dotychczasowym przeznaczeniem stało się niemożliwe bądź istotnie ograniczone, właściciel albo użytkownik wieczysty nieruchomości może [...] żądać od gminy: odszkodowania za poniesioną rzeczywistą szkodę albo wykupienia nieruchomości lub jej części”. ${ }^{32}$

P. Bojarski, Rekompensata za ograniczenia związane z ochroną przyrody, [w:] Teoretyczne podstawy ochrony przyrody, W. Radecki (red.), Wrocław 2006; J. Boć, K. Nowacki, E. Samborska-Boć, Ochrona środowiska, Wrocław 2002; W. Bołdok, Kilka uwag dotyczących obrotu nieruchomościami położonymi w rejonie parku narodowego, „Nowy Przegląd Notarialny” 2004, nr 3.

31 Dz.U. z 2012 r., poz. 647, z późn. zm.

32 Z. Niewiadomski, Planowanie przestrzenne. Zarys systemu, Warszawa 2003; Z. Niewiadomski (red.), Ustawa o planowaniu i zagospodarowaniu przestrzennym: komentarz, Warszawa 2011; Z. Niewiadomski, Samorząd terytorialny a planowanie przestrzenne. Nowe instytucje prawne, „Samorząd Terytorialny” 1995, nr 6, s. 48 i n.; E. Radziszewski, Planowanie i zagospodarowanie przestrzenne. Przepisy i komentarz, Warszawa 2006. 
W przypadku obszarów Natura 2000 roszczenie przewidziane w ustawie o planowaniu i zagospodarowaniu przestrzennym mogło by być wykorzystane, gdyby razem z ustanowieniem obszaru Natura 2000, jednocześnie uchwalono lub zmieniono miejscowy plan zagospodarowania przestrzennego. ${ }^{33}$ Co prawda plany zadań ochronnych mogą zawierać wskazania do zmiany istniejących lub uchwalenia nowych miejscowych planów zagospodarowania przestrzennego, ale biorąc pod uwagę chronologię aktów prawnych w tym zakresie roszczenia przewidziane w art. 129 Prawa ochrony środowiska powinny mieć pierwszeństwo, a ich realizacja zgodnie $\mathrm{z}$ art. 129 ust. 5 czyni roszczenia $\mathrm{z}$ art. 36 ust. 1 ustawy o planowaniu i zagospodarowaniu przestrzennym bezprzedmiotowymi.

Szczególny sposób rekompensat, który związany jest z wprowadzeniem na danym terenie obszarów Natura 2000 przewidziany jest w art. 36 ust. 3 ustawy o ochronie przyrody. W odróżnieniu od sądowego dochodzenia roszczeń przewidzianych w Prawie ochrony środowiska, procedura wskazana w ustawie o ochronie przyrody wskazuje na umowny sposób uregulowania utraconych dochodów wynikających z wprowadzenia obszarów Natura 2000. Należy podkreślić, że zakres możliwych roszczeń ogranicza się tylko do kwestii utraconych dochodów, a nie obniżenia wartości nieruchomości, czy możliwości jej wykupienia w całości lub części. Z procedury przewidzianej w art. 36 ust. 3 ustawy o ochronie przyrody nie mogą korzystać osoby, które mają roszczenia wynikające z ustanowienia parku narodowego.

Zgodnie z omawianym artykułem, jeżeli w wyniku wprowadzenia na danym terenie sieci obszarów Natura 2000, prowadzona działalność gospodarcza, rolna, leśna, łowiecka lub rybacka wymaga dostosowania do wymogów ochrony obszaru Natura 2000, a na tym obszarze nie mają zastosowania programy wsparcia z tytułu obniżenia dochodowości, regionalny dyrektor ochrony środowiska może zawrzeć umowę z właścicielem lub posiadaczem obszaru. Umowa ta nie może być zawarta z zarządcą nieruchomości Skarbu Państwa. ${ }^{34}$

W postanowieniach umownych należy określić wykaz niezbędnych działań, sposoby i terminy ich wykonania oraz warunki i terminy rozliczenia należności, za wykonane czynności oraz wartość rekompensaty za utracone dochody wynikające z wprowadzonych ograniczeń.

Powyższa procedura wprowadza wiele wymogów wstępnych, których spełnienie może prowadzić do zawarcia umowy. Po pierwsze na danym obszarze nie powinien mieć zastosowania żaden z programów pomocowych z tytułu obniżenia dochodowości. W Polsce może to być projektowana płatność dla obszarów Natura 2000,

33 Z. Wiśniewski, Szczególne uwarunkowania prawne uchwalania miejscowych planów zagospodarowania przestrzennego na obszarach Natura 2000. Plany miejscowe a plany ochrony tych obszarów, [w:] Problemy wdrażania systemu Natura 2000 w Polsce, A. Kaźmierska-Patrzyczna, M.A. Król (red.), Szczecin-Łódź-Poznań 2013, s. 375-398.

J. Engel, Natura 2000 w ocenach oddziaływania przedsięwzięć na środowisko, Warszawa 2010. 
czy środki pochodzące z Europejskiego Funduszu Społecznego, Europejskiego Funduszu Rozwoju Regionalnego, Funduszu Spójności, Europejskiego Funduszu Rolnego Rozwoju Obszarów Wiejskich, Europejskiego Funduszu Rybactwa, Instrumentu Finansowego na rzecz Środowiska LIFE+, VII Programu Ramowego.

Pytanie, które tutaj można postawić dotyczy określenia ,nie mają zastosowania programy wsparcia". Czy oznacza to, że w ogóle ich nie przewidziano na danym obszarze, czy też może to, czy rolnik się ubiegał o to wsparcie? Przyjmując pierwszą interpretację należy ocenić, że obecnie, w szczególności po 1 stycznia 2015 r., nie istnieją w Polsce obszary Natura 2000, gdzie potencjalnie nie miałyby zastosowania programy wsparcia w zakresie pomocy dla rolników. Takie podejście może czynić omawiane regulacje prawem martwym w odniesieniu do obszarów wiejskich, z którego nikt nie może skorzystać. Jeżeli przyjąć, że na wszystkich prawie tysiącu obszarach Natura 2000 w Polsce mają zastosowanie programy pomocowe, to umowa, o której mowa w art. 36 ust. 3 ustawy o ochronie przyrody nie będzie mogła być zawarta.

Po drugie działalność, która wymaga dostosowania do wymogów ochrony obszaru Natura 2000 musi dotyczyć działalności gospodarczej, ${ }^{35}$ rolnej, leśnej, łowieckiej lub rybackiej. Ograniczenia innych działalności nie powodują powstania roszczenia o zawarcie umowy określonej w art. 36 ust. 3 ustawy o ochronie przyrody.

Dopiero w sytuacji, gdy żaden z wymienionych środków pomocowych nie może mieć zastosowania, regionalny dyrektor ochrony środowiska może (chociaż istnieje spór w doktrynie, czy nie jest to obowiązek) zawrzeć umowę. Powinna być ona zawarta z właścicielem lub posiadaczem nieruchomości, z wyjątkiem zarządców nieruchomości Skarbu Państwa. Jak już podkreślano, w umowie określa się wysokość rekompensaty za utracone dochody wynikające z wprowadzonych ograniczeń.

Umowa może być zawarta na czas nieokreślony lub określony. W ustawie o ochronie przyrody nie wskazano także formy zawarcia umowy. Mając jednak na względzie jej przedmiot można sądzić, że dla celów dowodowych powinna ona zostać zawarta w formie pisemnej. Problemem pozostaje zabezpieczenie środków finansowych na realizację tych umów.

Kwestią niezwykle ważną do rozstrzygnięcia jest także zbieg roszczeń dotyczących rekompensat za ustanowienie obszarów Natura 2000 z Kodeksu cywilnego, Prawa ochrony środowiska i ustawy o ochronie przyrody. Wydaje się, że najpełniejszą ochronę rolnik ma zapewnioną w wyniku realizacji postanowień art. 129 Prawa ochrony środowiska. ${ }^{36}$ 
Obecne przepisy nie przewidują takich sytuacji, jak rekompensaty dla osób zamierzających prowadzić opisaną działalność na obszarze Natura 2000 (mających np. swoje nieruchomości w bezpośrednim sąsiedztwie obszaru Natura 2000). Nie ma tutaj regulacji chociażby podobnych do rozwiązań przyjętych w otulinie parków narodowych. ${ }^{37}$ Osoby te mogą dochodzić swoich roszczeń jedynie na podstawie ogólnych zasad prawa cywilnego. Rozwiązanie dotyczące rekompensat dla właścicieli nieruchomości w bezpośrednim sąsiedztwie obszarów Natura 2000 de lege ferenda mogłoby się znaleźć w ustawie o ochronie przyrody, z zastrzeżeniem, że taki podmiot wykazałby w sposób niebudzący zastrzeżeń swoją szkodę powstałą w wyniku wprowadzanych ograniczeń. Obecnie nie istnieje także szczególna ochrona prawna właścicieli nieruchomości bezpośrednio sąsiadujących z obszarem Natura 2000, w której mogliby się oni ubiegać o odszkodowanie z tytułu ewentualnego obniżenia wartości ich nieruchomości. De lege ferenda należy również rozważyć wprowadzenie rekompensat dla gmin, na których obszarach ustanawia się sieć Natura 2000. Ograniczenie działalności rolniczej na tych obszarach oznacza obniżenie dochodów nie tylko samych rolników, ale także gmin, które tracą część dochodu i stają się mniej konkurencyjne pod względem produkcji rolnej.

Problemy opisane w poprzednim akapicie wymagają interwencji ustawodawcy. Pozostawienie obecnie ich poza obszarem regulacji powoduje, że wprowadzanie obszarów Natura 2000 napotyka na trudności nie tylko prawne, ale także i społeczne obawy związane z nowym zagospodarowaniem prawie $20 \%$ powierzchni Polski. ${ }^{38}$

Przedstawiona analiza najważniejszych prawnych problemów rekompensat wynikających z ustanowienia obszarów Natura 2000 wskazuje na konieczność podjęcia dogłębnej analizy legislacyjnej związanej z istniejącymi przepisami. Należy przede wszystkim rozstrzygnąć warunki, w jakich rolnik - właściciel nieruchomości może dochodzić rekompensaty za wprowadzone ograniczenia. Obecny stan prawny, gdzie poszczególne roszczenia wynikają z kilku aktów prawnych rangi ustawowej nie sprzyjają jasności przepisów w tym zakresie. Trudności sprawia również rozstrzygnięcie hierarchii tych roszczeń i ich realizacji w przypadku ich zbiegu. Należy zwrócić uwagę, że można spotkać tutaj uregulowaną ustawowo procedurę cywilną dochodzenia roszczeń oraz również znajdującą swe źródło w ustawie procedurę szczególnej umowy zawieranej przez regionalnego dyrektora ochrony środowiska.

ski, B. Rakoczy, Prawo ochrony środowiska: komentarz, Warszawa 2008.

K. Gruszecki, Następstwa prawne wyznaczenia otuliny parków narodowych oraz rezerwatów przyrody, "Casus" 2006, nr 1, s. 23; P. Czechowski, A. Niewiadomski, Natura 200 a parki narodowe - wybrane problemy prawne, [w:] Administracja publiczna a ochrona przyrody. Zagadnienia ekonomiczne, społeczne oraz prawne, M. Górski, D. Niedziółka, R. Stec, D. Strus (red.), Warszawa 2012, s. 101-116. cja publiczna a ochrona przyrody. Zagadnienia ekonomiczne, społeczne oraz prawne, M. Górski, D. Niedziółka, R. Stec, D. Strus (red.), Warszawa 2012, s. 87-98; S.C.F. de Piérola, Natura 2000 i społeczeństwo: instrumenty komunikacji społecznej w zarządzaniu Siecią Natura 2000, Warszawa 2009; M. Micińska, Udział społeczeństwa w ochronie środowiska, Toruń 2011. 
Ustawodawca wypełniając zadania ochrony przyrody i środowiska naturalnego z uwzględnieniem idei zrównoważonego rozwoju ${ }^{39}$ nie powinien zapominać o społecznej akceptowalności wprowadzonych rozwiązań. Ochrona przyrody powinna zawierać w sobie także pierwiastek ochrony prawa własności nieruchomości ${ }^{40} \mathrm{Te}$ dwie zasady nie powinny pozostawać ze sobą w nieustannym konflikcie. ${ }^{41}$ Ich harmonijne występowanie wydaje się nierealne, ale ewentualne wprowadzane zmiany mogą pozwolić na zwiększenie podmiotowości właściciela na obszarach Natura $2000 .{ }^{42} \mathrm{~W}$ przeciwnym razie długotrwałe dochodzenie rekompensat i praktyczna niepewność ich otrzymania mogą podważyć zaufanie rolników - obywateli do państwa prawa. ${ }^{43}$

Z. Bukowski, Zrównoważony rozwój w systemie prawa, Toruń 2009; Uwarunkowania ochrony środowiska: aspekty krajowe, unijne, międzynarodowe; E. Czech (red.), Warszawa 2006; A. Niewiadomski, Europejska Sieć Ekologiczna Natura 2000 a zrównoważony rozwój obszarów wiejskich, „Studia luridica Agraria” 2013, t. XI, s. 293304.

40 B. Rakoczy, Ograniczenie praw i wolności jednostki ze względu na ochronę środowiska w Konstytucji Rzeczypospolitej Polskiej, Toruń 2009; B. Rakoczy, Komentarz do ustawy o zapobieganiu szkodom w środowisku i ich naprawie, Warszawa 2008; B. Wierzbowski, B. Rakoczy, Podstawy prawa ochrony środowiska, Warszawa 2007. M. Woźniak, Natura 2000 jako obszar konfliktogenny, [w:] A. Kaźmierska-Patrzyczna, M.A. Król, Problemy wdrażania systemu Natura 2000 w Polsce, Szczecin-Łódź-Poznań, 2013, s. 237-255; M. Głogowska, Modele konfliktów społecznych na obszarach Natura 2000 w Polsce, [w:] A. Kaźmierska-Patrzyczna, M.A. Król, Problemy wdrażania systemu Natura 2000 w Polsce, Szczecin-Łódź-Poznań 2013, s. 257-272.

42 M. Borowiak, Rola norm konstytucyjnych w kształtowaniu prawodawstwa w dziedzinie ochrony przyrody, [w:] Trwałość i efektywność ochrony przyrody w polskich parkach narodowych, A. Andrzejewska, A. Lubański (red.),Warszawa 2009.

43 Z. Bukowski, Konstytucyjne podstawy obowiązków państwa w zakresie ochrony środowiska, „Prawo i środowisko" 2002, nr 4, s. 63 i n. 
LEGAL ISSUES FORMS OF COMPENSATION FOR THE ESTABLISHMENT OF CONSERVATION - NATURA 2000 SITES IN THE RURAL AREAS

Keywords: Nature 2000, the conservation of nature, environmental protection, ownership of the real estate

The article describes the fundamental issues of limiting property rights in connection with introducing the form of the conservation of nature on the given area $\mathrm{Na}$ ture 2000. Regulations of environment protection laws and the act on the conservation of nature which appropriate claims will grant property owners were shown. Also existing legal conflicts were described in this area. The choice about the manner of the compensation for implemented restrictions to a large extent is hampering by the economical functioning of farmers in areas Nature 2000. What is more, a foreign aid budget coming from European Funds seems insufficient. 